\title{
Antimicrobial metabolites produced by an intertidal Acremonium furcatum
}

\author{
Gabriela L. Gallardo a , Matías Butler ${ }^{\text {a }}$, Mariana L. Gallo ${ }^{\text {a }}$, M. Alejandra Rodríguez ${ }^{\text {, }}$, \\ Marcos N. Eberlin ${ }^{c}$, Gabriela M. Cabrera ${ }^{\mathrm{a}, *}$ \\ a Departamento de Química Orgánica, Facultad de Ciencias Exactas y Naturales, Universidad de Buenos Aires, \\ Ciudad Universitaria, Pab. II, 1428 Buenos Aires, Argentina \\ b DBBE, FCEN, UBA, Ciudad Universitaria, Pab. II, 1428 Buenos Aires, Argentina \\ ${ }^{c}$ Thomson Mass Spectrometry Laboratory, Instituto de Química, Universidade Estadual de Campinas, 13083-970 Campinas, SP, Brazil
}

Received 13 January 2006; received in revised form 27 June 2006

Available online 7 September 2006

\begin{abstract}
In a screening for antimicrobial metabolites, amides of D-allo- and L-isoleucine derivatives were isolated from the culture of a marine strain of Acremonium furcatum. Structural elucidation of these compounds was performed by analysis of spectroscopic data and confirmed by synthesis. All of the compounds, natural and synthetic intermediates, were bioassayed against bacteria and phytopathogenic fungi, with many showing remarkable antifungal activities.
\end{abstract}

(c) 2006 Elsevier Ltd. All rights reserved.

Keywords: Acremonium furcatum; Marine fungi; Isoleucinol; Isoleucinaldehyde; Isoleucine derivatives; Antifungal activity; Fusarium virguliforme; Colletotrichum truncatum

\section{Introduction}

Since marine microorganisms grow in unique and extreme habitats, they may have the capability to produce unique and unusual metabolites. In particular, it is known that marine fungi, native or adapted to the environment, are an important source of bioactive natural products (Schiehser et al., 1986; Fenical and Jensen, 1993; Kobayashi and Ishibashi, 1993; Davidson, 1995; Bringmann et al., 2005). In the course of screening for new bioactive metabolites with potential use in agriculture from fungal cultures of diverse origin (Cabrera et al., 2002; Gallo et al., 2004; Levy et al., 2003), we investigated a strain Acremonium furcatum isolated from an intertidal sediment sample. The extract of the culture medium of this fungus produced new metabolites with antimicrobial activity against bacteria and phytopathogenic fungi. This report

\footnotetext{
${ }^{*}$ Corresponding author. Tel./fax: +54 1145763376.

E-mail address: gabyc@qo.fcen.uba.ar (G.M. Cabrera).
}

deals with the fermentation, isolation, structure elucidation, synthesis and biological activity of these compounds, which are amides of the corresponding amino alcohols and amino aldehydes of D-allo- and L-isoleucine.

\section{Results and discussion}

The organic extract of the culture media of A. furcatum, isolated from an intertidal sediment sample (collected on the coast of Buenos Aires, Argentina), showed moderate antimicrobial activity against Bacillus subtilis, Staphylococcus aureus, Escherichia coli and Botrytis cynerea, and a very simple pattern by thin layer chromatography (TLC). Prep. TLC was then employed and two fractions in a 10:1 ratio were obtained. The major and more polar fraction showed, by ${ }^{1} \mathrm{H}$ NMR spectroscopy, three olefinic protons at $\delta 6.88$ $(1 \mathrm{H}, d, 11.0 \mathrm{~Hz}), 6.33(1 \mathrm{H}, d d q, 15.0,11.0$ and $1.5 \mathrm{~Hz})$ and $6.03(1 \mathrm{H}, d q, 15.0$ and $6.9 \mathrm{~Hz})$, one broad signal at $5.90 \mathrm{ppm}$, five complex multiplets at 4.00, 3.70, 1.70, 
$1.46-1.50$ and $1.23 \mathrm{ppm}$, two methyl protons attached to $\mathrm{sp}^{2}$ carbons at $\delta 1.86(d, 6.9 \mathrm{~Hz})$ and $1.95(s)$, and two set of methyl groups in a 3:1 ratio, the major group at $\delta 0.93$ $(t, 7.4 \mathrm{~Hz})$ and $0.93(d, 7.0 \mathrm{~Hz})$ and the minor at $0.91(t$, $7.0 \mathrm{~Hz})$ and $0.95(d, 6.8 \mathrm{~Hz})$. These data indicated that the fraction was actually a mixture of two compounds 1 and $\mathbf{2}$, in an approximately $3: 1$ ratio, which were very similar in nature. The high field signals resembled those of amino acids and the similarity between both compounds suggested an epimeric mixture.

Exhaustive efforts to separate this mixture using HPLC, employing different stationary and mobile phases, or employing enzymes to selectively acylate one epimer (after knowing the structures), were only partially successful - the major compound 1, obtained via HPLC separation with a chiral stationary phase, was only of sufficient purity for full characterization. Thus, a provisional structural elucidation of compound 2 was performed on the natural mixture (Che et al., 2002).

Compound 1 has the molecular formula $\mathrm{C}_{13} \mathrm{H}_{23} \mathrm{NO}_{2}$, as determined from its high-resolution electron ionization mass spectrometry (EIMS). A COSY H,H experiment and irradiation of the olefinic protons allowed unambiguous determination of the presence of a $\mathrm{CH}_{3} \mathrm{CH}=\mathrm{CH}-\mathrm{CH}=\mathrm{C}\left(\mathrm{CH}_{3}\right)$ moiety and, taking into account the coupling constants, an $E$ configuration for the terminal double bond was determined. The COSY spectrum also showed that the methine proton at $\delta 4.00(\mathrm{CH})$ correlated with protons at $\delta 3.70$ $\left(\mathrm{CH}_{2}\right)$ and $1.72(\mathrm{CH})$.

The ${ }^{13} \mathrm{C}$ NMR spectrum exhibited four olefinic carbons $(\delta 136.3 d, 134.2 d, 127.3 s$ and $126.9 d)$ and two methyl groups at 18.6 and $12.7 \mathrm{ppm}$, corresponding to the above-mentioned olefinic moiety, plus another seven signals, which were all accompanied by a duplicate resonance of lower intensity in the ${ }^{13} \mathrm{C}$ NMR spectrum of the mixture. One of these carbons was a carbonyl at $170.3 \mathrm{ppm}$, while the other carbons were a $\mathrm{CH}_{2}$ attached to an oxygen at $\delta$ 64.0 , a $\mathrm{CH}$ linked to a heteroatom at $55.3 \mathrm{ppm}$ and aliphatic carbons at $35.5(d), 26.3(t), 14.8$ and $11.3(q)$. The multiplicities were determined by a distortionless enhancement by polarization transfer (DEPT) experiment.

The methyl group at $1.95 \mathrm{ppm}$ correlated with the carbonyl in a heteronuclear multiple bond correlation (HMBC) experiment, indicating that an acid derivative $\mathrm{CH}_{3} \mathrm{CH}=$ $\mathrm{CH}-\mathrm{CH}=\mathrm{C}\left(\mathrm{CH}_{3}\right) \mathrm{COX}$ was present and attached to the other part of the molecule. The $E$ configuration for the second double bond was determined by comparison with the spectroscopic literature data for the corresponding methyl ester, previously synthesized (Ceroni and Séquin, 1982).

A comparison of the remaining high-field proton and carbon signals with the literature data for amino acids (MacDonald et al., 1976) showed that compound 1 contained a substructure similar to the amino acid isoleucine, but in a reduced way, isoleucinol, as $2 \mathrm{D}$ experiments revealed. The connectivities observed in the HMBC experiment are shown in Fig. 2. The structure of compound 1 was thus assigned as the 2-methyl-hexa-2,4-dienoic acid, isoleucinol amide.

Similar spectroscopic analysis was performed on the mixture, revealing the presence of a minor component with the same structural features as $\mathbf{1}$. The 2D NMR spectroscopic experiments showed that all the correlations in the high field region were merely duplicated and partially overlapped. Furthermore, the available ${ }^{13} \mathrm{C}$ NMR spectroscopic data for amino acids (MacDonald et al., 1976) suggested that $\mathbf{1}$ and $\mathbf{2}$ were a 3:1 mixture of C-2 epimers, i.e. D-allo-IleOH:L-IleOH or L-allo-IleOH:D-IleOH, indicating that the major epimer was either D-allo or L-allo-IleOH, whereas the minor component was L- or D-IleOH.

The mixture of compounds 1 and $\mathbf{2}$ was oxidized and hydrolyzed to determine the absolute configuration of each compound, with the resulting amino acids analyzed by HPLC using a chiral column, Chirex (D) Penicillamine, yielding peaks with retention times of 29.9 and $39.9 \mathrm{~min}$, identical to authentic samples of D-allo-Ile and L-Ile, respectively. This result thus established the absolute configuration as being $2^{\prime} R, 3^{\prime} S$ for the major epimer 1 , and $2^{\prime} S, 3^{\prime} S$ for the minor compound 2 . With this rationale, the structures of $\mathbf{1}$ and $\mathbf{2}$ were established as shown in Fig. 1.

The synthesis of compounds $\mathbf{1}$ and $\mathbf{2}$ was performed to confirm the structures, to determine the physical constants of compound $\mathbf{2}$, and to fundamentally evaluate the biological properties of each individual compound. For this

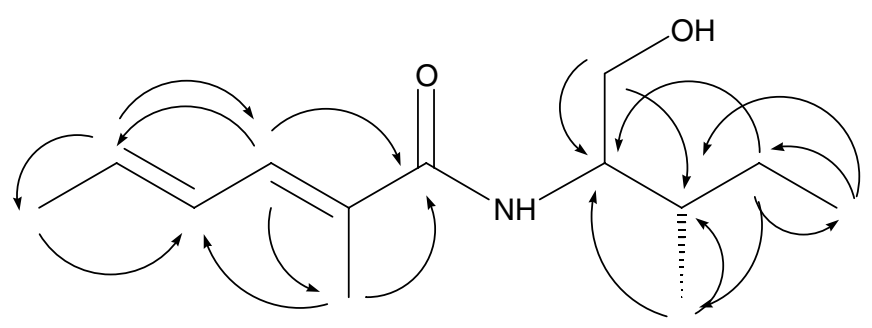

Fig. 2. Observed HMBC correlations.

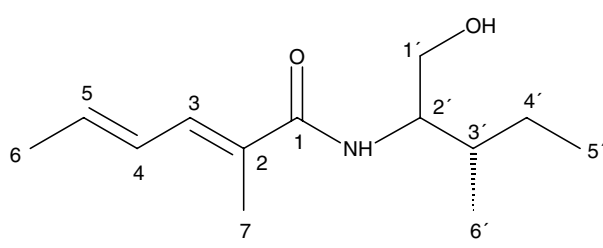

$12^{\prime} \mathrm{R}$

22 'S<smiles>CC=CC=C(C)C(=O)NC(C)C(C)CC</smiles>

$32^{\prime} \mathrm{R}$

42 'S

Fig. 1. Isolated compounds from Acremonium furcatum. 
purpose, the general methodology of Hamada et al. (1987) was employed. Although some modifications were made to improve yields, in general, they were lower due to simple decomposition of the unsaturated acid subunit. This subunit was synthesized instead according to the procedure of Ceroni and Séquin (1982) as shown in Fig. 3. The spectroscopic data of the synthetic compounds $\mathbf{1}$ and $\mathbf{2}$ were in full accordance with those of the natural metabolites.

The minor and less polar fraction isolated from the extract had similar ${ }^{1} \mathrm{H}$ and ${ }^{13} \mathrm{C}$ NMR spectra that of compounds 1 and 2. It differed, however, by the absence of the $\mathrm{CH}_{2} \mathrm{OH}$ moiety and the presence of an aldehydic functionality at $\delta 200.2\left({ }^{13} \mathrm{C}\right.$ NMR $)$ and 9.73 and $9.67 \mathrm{ppm}\left(s,{ }^{1} \mathrm{H}\right.$ NMR), respectively, suggesting structures $\mathbf{3}$ and $\mathbf{4}$ as shown in Fig. 1. An epimeric mixture was also evident, as the signals of the aminoaldehyde unit were duplicated in both spectra. Due to the small amount of this mixture, and its instability, it was not possible to perform any further analysis. The presence of the epimers, D-allo- and L-Ile-isoleucinaldehyde, was thus assumed on the basis of the absolute stereochemistry of $\mathbf{1}$ and $\mathbf{2}$. The synthesis of $N$-Boc-L-isoleucinaldehyde $\mathbf{1 0}$ (Fig. 4) was made to confirm the assignments and identify unambiguously both epimers. The ${ }^{1} \mathrm{H}$ and ${ }^{13} \mathrm{C}$ NMR spectroscopic data for $\mathbf{1 0}$ were in full agreement with those of the minor epimer $\mathbf{4}$, confirming its identity.

A time-course of the production of compounds $\mathbf{1}+\mathbf{2}$ was carried out in an attempt to explain the reason why both epimers were present in the extract (Fig. 5). Two interesting findings were made. First, the $\mathrm{pH}$ of the medium became basic after day 8 . Second, the presence of the minor metabolites 3 and $\mathbf{4}$ were observed on all days, via TLC of the extract, in approximately the same relative proportions to that of the epimers $\mathbf{1}$ and $\mathbf{2}$. Both results thus suggested that the aldehydic precursors of the alcohols epimerize due to a keto-enol equilibrium in the basic media, thereby producing an epimeric mixture of alcohols.

The synthetic compounds $\mathbf{1}$ and $\mathbf{2}$, and the synthetic intermediates 5-8 and 10, were bioassayed against the bacteria B. subtilis, S. aureus, E. coli and the fungi Fusarium virguliforme (causal agent of Sudden Death Syndrome in

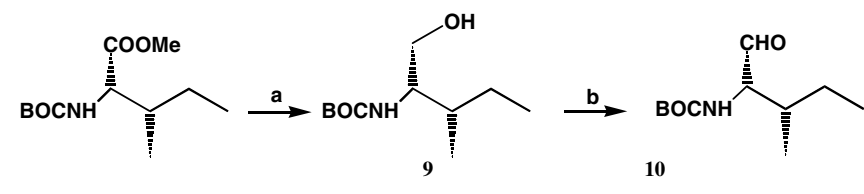

a. $\mathrm{LiBH}_{4} / \mathrm{EtOH} \quad$ b. $\mathrm{PCC} / \mathrm{CH}_{2} \mathrm{Cl}_{2}$

Fig. 4. Synthetic route to compound $\mathbf{1 0 .}$

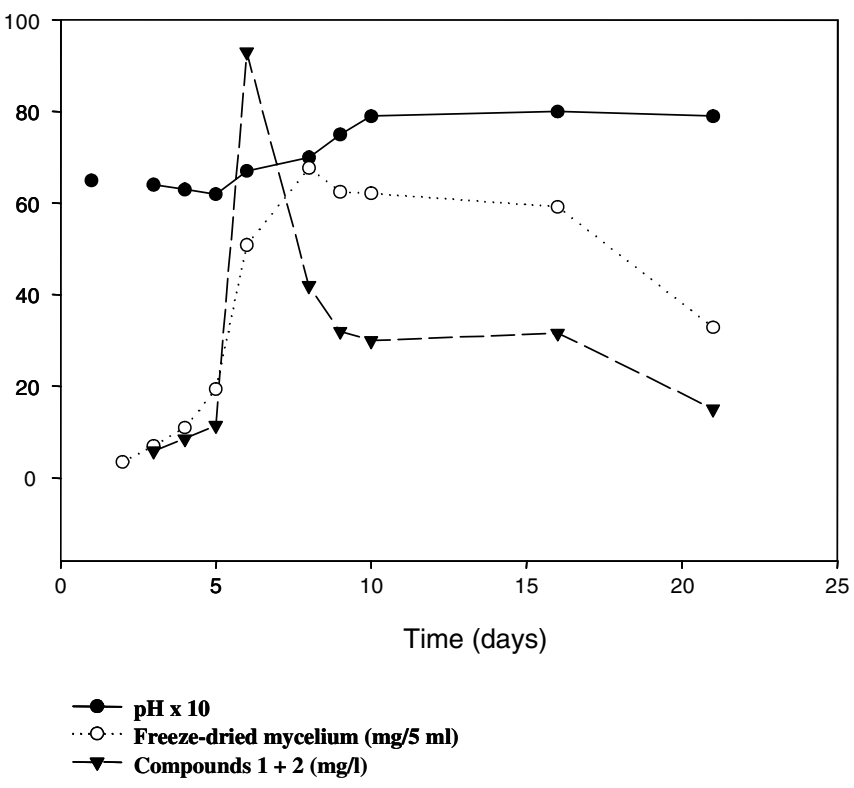

Fig. 5. Time-course production of $\mathbf{1}$ and $\mathbf{2}$.

soy bean) Colletotrichum truncatum (responsible for anthracnose disease), Macrophomina phaseolina (causal agent of charcoal rot in beans), B. cynerea and Aspergillus fumigatus. The results are shown in Table 2. Interestingly, the L-derivatives $\mathbf{2}$ and $\mathbf{8}$ showed moderate antibiotic activity and low, if any, antifungal activity, whilst the D-allo derivatives 1 and 7 showed antifungal activity. Nonetheless, the acid $\mathbf{6}$ and the ester $\mathbf{5}$ displayed the greatest antifungal activity, in the same order as benomyl, a commercial antifungal product. The natural $(2 Z, 4 E)$ isomer of $\mathbf{6}$ was previously reported as an antifungal metabolite against other fungal strains (Proksa et al., 1992).<smiles>CC=CC(=O)[CH+]C(C)C(=O)OCC</smiles>

Fig. 3. Synthetic route to compounds $\mathbf{1}$ and $\mathbf{2}$. 
Table 1

NMR spectroscopic data of compounds 1 and $2\left(\mathrm{CDCl}_{3}\right), \delta$ in ppm, $J$ in $\mathrm{Hz}$

\begin{tabular}{|c|c|c|c|c|}
\hline & \multicolumn{2}{|c|}{ Compound 1} & \multicolumn{2}{|c|}{ Compound 2} \\
\hline & ${ }^{13} \mathrm{C}$ & ${ }^{1} \mathrm{H}$ & ${ }^{13} \mathrm{C}$ & ${ }^{1} \mathrm{H}$ \\
\hline 1 & 170.3 & & 170.1 & \\
\hline 2 & 127.3 & & 126.9 & \\
\hline 3 & 134.2 & $6.88 d(11.0)$ & 134.2 & $6.88 d(11.0)$ \\
\hline 4 & 126.9 & $\begin{array}{l}6.33 d d q \\
(15.0,11.0,1.5)\end{array}$ & 126.9 & $\begin{array}{l}6.33 d d q \\
(15.0,11.0,1.5)\end{array}$ \\
\hline 5 & 136.3 & $6.03 d q(15.0,6.9)$ & 136.3 & $6.03 d q(15.0,6.9)$ \\
\hline 6 & 18.6 & $1.86 d(6.9)$ & 18.6 & $1.86 d(6.9)$ \\
\hline 7 & 12.7 & $1.95 s$ & 12.7 & $1.95 \mathrm{~s}$ \\
\hline $1^{\prime}$ & 64.0 & $\begin{array}{l}3.70 d d(11.2,4.1) \\
3.67 d d(11.2,6.5)\end{array}$ & 63.4 & $3.74 \mathrm{~m}^{\mathrm{a}}$ \\
\hline $2^{\prime}$ & 55.3 & $4.00 \mathrm{~m}$ & 55.9 & $3.88 \mathrm{~m}$ \\
\hline $3^{\prime}$ & 35.5 & $1.72 \mathrm{~m}$ & 35.7 & $1.70 \mathrm{~m}$ \\
\hline $4^{\prime}$ & 26.3 & $1.23,1.46 \mathrm{~m}$ & 25.5 & $1.23,1.51 \mathrm{~m}$ \\
\hline $5^{\prime}$ & 11.3 & $0.93 t(7.4)$ & 11.3 & $0.91 t(7.0)$ \\
\hline $6^{\prime}$ & 14.8 & $0.93 d(7.0)$ & 15.5 & $0.95 d(6.8)$ \\
\hline $\mathrm{N} H$ & & $5.90 d(7.7)$ & & $5.92^{\mathrm{b}}$ \\
\hline
\end{tabular}

Assignments based on COSY H,H, HSQC and HMBC experiments.

Multiplicities determined by DEPT.

a Overlapped.

${ }^{\mathrm{b}}$ Partially overlapped.

Several isoleucine derivatives were previously isolated from different microbial strains as C-amides (Kern et al., 1985), esters (Iwamoto et al., 1990) or unknowns (Kawakami et al., 1978). In particular, isoleucinol was reported as a C-terminal amino acid of peptaibols (Jaworski and Bruckner, 2001).

The acid subunit was previously found as an ester of an antifungal compound isolated from Graphium putredinis (Kennedy et al., 1998) and the above-mentioned antifungal isomer $(2 Z, 4 E)$ was identified as a free acid from culture extracts of Penicillium vermiculatum (Proksa et al., 1992). It is noteworthy that, although the strain grew well in the same medium without artificial sea water and also in malt extract agar, the compounds were not produced, even at trace levels, under those conditions. It is known that metabolite profiles expressed by fungi are sometimes dependent on media salinity (Rabaek et al., 1998; Christo- phersen et al., 1999) although this question deserves still an explanation.

Acremonium is a wide-spread fungal genus, noted for their secondary metabolite content, with around 90 compounds having been reported from fungi of this genus (Abdel-Lateff et al., 2002), including alkaloids (MundayFinch et al., 1995), terpenoids (Kawashima et al., 1994), aromatic compounds (Toki et al., 1994) and peptides (Sharman et al., 1996). Particularly, several marine Acremonium strains have been isolated, including strains of $A$. furcatum (Koh et al., 2002), and antioxidant hydroquinones (Abdel-Lateff et al., 2002), anti-inflammatory oxepines and weak antifungal quinolines (Belofsky et al., 2000) were isolated and identified from marine strains of this genus.

\subsection{Concluding remarks}

In summary, we have isolated and identified two new antimicrobial amino alcohol derivatives $\mathbf{1}$ and $\mathbf{2}$, which are epimers biosynthesized from the corresponding aldehydes, that were also isolated. A rapid epimerization of the aldehydes could explain these data, as a basic $\mathrm{pH}$ was produced in the medium during fermentation. The structure elucidations were confirmed by total synthesis of compounds $\mathbf{1}$ and 2, and remarkably, the two synthetic intermediates $\mathbf{5}$ and $\mathbf{6}$, exhibited higher antifungal activity against phytopathogenic fungi, comparable to that of the commercial agent benomyl.

\section{Experimental}

\subsection{General}

FTIR spectra were recorded on a Nicolet Magna-IR 550. The UV spectra were recorded on a Hewlett-Packard 8451 A diode array spectrophotometer, whereas optical rotations were acquired on a Perkin-Elmer polarimeter 343. NMR spectra were recorded on a Bruker AM-500 instrument at $500.13 \mathrm{MHz}$ for ${ }^{1} \mathrm{H}$ and at $125.13 \mathrm{MHz}$ for

Table 2

Antimicrobial activities of natural and synthetic compounds

\begin{tabular}{|c|c|c|c|c|c|c|c|c|c|}
\hline & 1 & 2 & 5 & 6 & 7 & 8 & 10 & $\mathbf{A}$ & $\mathbf{B}$ \\
\hline Escherichia coli ${ }^{\mathrm{a}}$ & - & 7 & - & - & - & 7 & - & 9 & $\overline{\mathrm{nd}}$ \\
\hline Bacillus subtilis ${ }^{\mathrm{a}}$ & - & 9 & 15 & 9 & - & 10 & - & 10 & nd \\
\hline Staphylococcus aureus ${ }^{\mathrm{a}}$ & 7 & - & 15 & 9 & - & - & - & 8 & nd \\
\hline Aspergillus fumigatus ${ }^{\mathrm{b}}$ & 15 & $10^{\mathrm{c}}$ & $24(1 \mu \mathrm{g})$ & $29(1 \mu \mathrm{g})$ & 10 & - & 14 & 10 & 20 \\
\hline Botrytis cynerea ${ }^{\mathrm{b}}$ & 15 & - & $12(5 \mu \mathrm{g})$ & $15(1 \mu \mathrm{g})$ & - & - & - & 12 & 28 \\
\hline Colletotrichum truncatum ${ }^{\mathrm{b}}$ & 10 & 5 & $10(10 \mu \mathrm{g})$ & $12(1 \mu \mathrm{g})$ & 8 & - & 11 & nd & 25 \\
\hline
\end{tabular}

Diameter of inhibition zone in $\mathrm{mm}(\mathrm{MIC} \mu \mathrm{g} / \mathrm{pt})$.

nd, not determined.

a $50 \mu \mathrm{g} / 6 \mathrm{~mm}$ disk was used.

b $50 \mu \mathrm{g} / \mathrm{spot}$ was used except the concentration shown in parentheses and B: benomyl ( $25 \mu \mathrm{g} / \mathrm{spot})$. A: a mixture of natural products 1 and 2 .

${ }^{c}$ Diffuse halos. 
${ }^{13} \mathrm{C}$ NMR. EIMS was carried out on a mass spectrometer Trio-2 VG Masslab (Manchester, UK), whereas HR-MS employed a Fisons VG AutoSpec. Some of the HR-MS were run at the Washington University Resource (St. Louis, Missourri) for Biomedical and Bio-organic Mass Spectrometry.

\subsection{Fungal strain}

The fungus $A$. furcatum (F. \& R. Moreau) ex W. Gams, was isolated from an intertidal marine sediment sample collected at Miramar, Province of Buenos Aires, Argentina and classified by Dr. J. E. Wright (PRHIDEB-CONICET, Depto de Biodiversidad y Biología Experimental DBBE, FCEN, UBA) and Dr. M. A. Rodriguez (DBBE, FCENUBA). The strain was deposited in the BAFC Culture Collection (FCEN-UBA, CONICET) under the Accession Number BAFC 51375.

\subsection{Fermentation}

Fermentation was carried out using a medium which consisted of peptone $1 \%$, yeast extract $0.5 \%$, dextrose $1 \%$ and artificial sea water (Instant Ocean) 100\%. Erlenmeyer flasks $(250 \mathrm{ml})$ containing $75 \mathrm{ml}$ of medium were inoculated with agar slants of the strain. Fermentation was carried out at $25^{\circ} \mathrm{C}$ for 20 days under static conditions.

\subsection{Extraction and isolation}

The fermentation broth was filtered and the filtrate was partitioned with EtOAc. The crude organic extract was subjected to prep. TLC on silica gel $(0.25 \mathrm{~mm})$, eluting with EtOAc: $\mathrm{CH}_{2} \mathrm{Cl}_{2}$ 1:1, yielding one band containing compounds 1 and $2\left(29 \mathrm{mg} / 1, R_{\mathrm{F}} 0.5\right)$ and another with compounds 3 and $4\left(1 \mathrm{mg} / 1, R_{\mathrm{F}} 0.7\right)$. Both bands were detected by UV at $254 \mathrm{~nm}$, and EtOAc was employed to recover the compounds from the adsorbent. Compounds 1 and $\mathbf{2}$ were separated by HPLC (Chirex (D) Penicillamine column-Phenomenex, $250 \times 4.60 \mathrm{~mm}, \mathrm{CuSO}_{4} 1 \mathrm{mM}: \mathrm{MeOH}$ $6: 4,0.7 \mathrm{ml} / \mathrm{min}, \mathrm{UV} 215 \mathrm{~nm}$ ). A re-purification of the major peak by peak shaving was done employing the same conditions as above to yield pure $\mathbf{1}(1 \mathrm{mg})$.

\subsection{Time-course of production of compounds 1 and 2}

A loopful of the cells of a slant culture of the strain was inoculated in $75 \mathrm{ml}$ of the above liquid medium in a $250 \mathrm{ml}$ Erlenmeyer flask and incubated on a rotary shaker at room temperature for one day to give a seed culture. An aliquot of this culture $(1 \mathrm{ml})$ was transferred quantitatively onto $50 \mathrm{ml}$ of medium in $40 \times 125 \mathrm{ml}$ Erlenmeyer flasks. Two of these cultures were filtered every day with the mycelia freeze-dried and the media extracted with EtOAc $(20 \mathrm{ml})$; the aqueous layers were re-extracted with EtOAc $(2 \times 20 \mathrm{ml})$. The organic layers were combined and evaporated in vacuo with the amount of compounds $\mathbf{1}+\mathbf{2}$ determined by HPLC (Column: YMC-Pack ODS-A, $250 \times 4.6 \mathrm{~mm}, 5 \mu \mathrm{m} ; \mathrm{MeOH}-\mathrm{H}_{2} \mathrm{O} 6: 4,0.5 \mathrm{ml} / \mathrm{min}$, UV $230 \mathrm{~nm})$.

\subsection{Physico-chemical properties of compounds}

\subsubsection{Compound 1}

$(2 E, 4 E)$-2-methyl-hexa-2,4-dienoic acid $\left(2^{\prime} R, 3^{\prime} S\right)$-isoleucinol amide or $((2 E, 4 E)-2$-methyl-hexa-2,4-dienoic acid $\left[\left(1^{\prime} R, 2^{\prime} S\right)\right.$-1-hydroxymethyl-2-methyl-butyl]-amide). Oil. $[\alpha]_{\mathrm{D}}=-50\left(\mathrm{CHCl}_{3}, \mathrm{c} 0.1\right)$. For ${ }^{1} \mathrm{H}$ NMR and ${ }^{13} \mathrm{C}$ NMR spectra, see Table 1. HREIMS $m / z[\mathrm{M}]^{+}$, found 225.17300, calc. for $\mathrm{C}_{13} \mathrm{H}_{23} \mathrm{NO}_{2} 225.17288(\Delta m=0.4 \mathrm{ppm}), \quad[\mathrm{M}+1]^{+}$, found 226.17656, calc. for ${ }^{13} \mathrm{C}^{12} \mathrm{C}_{12} \mathrm{H}_{23} \mathrm{NO}_{2} 226.17623(\Delta$ $m=0.4 \mathrm{ppm}$ ). EIMS $70 \mathrm{eV}, m / z$ (rel. int.): $225[\mathrm{M}]^{+\cdot}(8)$, $210 \quad\left[\begin{array}{lllll}\left.\mathrm{M}-\mathrm{CH}_{3}\right]^{+} & (3), \quad 207 \quad\left[\mathrm{M}-\mathrm{H}_{2} \mathrm{O}\right]^{+\cdot} \quad \text { (3), } & 194\end{array}\right.$ $\left[\mathrm{M}-\mathrm{CH}_{2} \mathrm{OH}\right]^{+\cdot}$ (24), 126 (22), $109\left[\mathrm{RCO}^{+}\right.$(100), 81 (69).

\subsubsection{Compound 2}

$(2 E, 4 E)$-2-methyl-hexa-2,4-dienoic acid $\left(2^{\prime} S, 3^{\prime} S\right)$-isoleu-

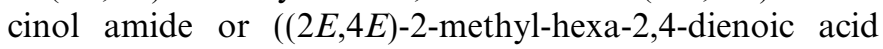
$\left[\left(1^{\prime} R, 2^{\prime} S\right)\right.$-1-hydroxymethyl-2-methyl-butyl]-amide). For ${ }^{1} \mathrm{H}$ NMR and ${ }^{13} \mathrm{C}$ NMR spectra (in the natural mixture), see Table 1.

\subsubsection{Compounds 3 and 4}

$\left(2^{\prime} R, 3^{\prime} S\right)$ and $\left(2^{\prime} S, 3^{\prime} S\right)[(2 E, 4 E)$-2-Methyl-hexa-2,4-dienoic acid isoleucinaldehyde] or $\left(\left(1^{\prime} R, 2^{\prime} S\right)\right.$ and $\left(1^{\prime} S, 2^{\prime} S\right)$ $(2 E, 4 E)$-2-methyl-hexa-2,4-dienoic acid (1-formyl-2methyl-butyl)-amide). ${ }^{1} \mathrm{H}$ NMR $\left(500 \mathrm{MHz}, \mathrm{CDCl}_{3}\right): \delta$ $9.73\left(s, \mathrm{H}-1_{\mathrm{m}}^{\prime}\right), 9.67\left(s, \mathrm{H}-1_{\mathrm{M}}^{\prime}\right), 6.89(m, \mathrm{H}-3), 6.34(m, \mathrm{H}-$ 4), 6.06 ( $m, \mathrm{H}-5), 5.85(\mathrm{NH}), 3.73\left(m, \mathrm{H}-2^{\prime}\right), 1.96$ ( $\left.s, \mathrm{H}-7\right)$, $1.87(d, J=6.4 \mathrm{~Hz}, \mathrm{H}-6), 1.30-40\left(m, \mathrm{H}-4^{\prime}\right), 0.94(t$, $\left.J=6.9 \mathrm{~Hz}, \mathrm{H}-5_{\mathrm{M}}^{\prime}\right), 0.94\left(d, J=6.6 \mathrm{~Hz}, \mathrm{H}-6_{\mathrm{M}}^{\prime}\right), 0.99(d$, $J=7.0 \mathrm{~Hz}, \mathrm{H}-6_{\mathrm{m}}^{\prime}$ ), 0.97 (overlapped, H- $5_{\mathrm{m}}^{\prime}$ ). ${ }^{13} \mathrm{C} \mathrm{NMR}$ $\left(125 \mathrm{MHz}, \mathrm{CDCl}_{3}\right): \delta 200.2\left(d, \mathrm{C}-1^{\prime}\right), 169.5\left(s, \mathrm{C}-1_{\mathrm{M}}\right)$, $169.2\left(s, \mathrm{C}-1_{\mathrm{m}}\right), 136.5$ (d, C-5), $134.4(d, \mathrm{C}-3), 127.0$ (C2,4), $62.0\left(d, \mathrm{C}-2_{\mathrm{M}}^{\prime}\right), 63.1\left(d, \mathrm{C}-2_{\mathrm{m}}^{\prime}\right), 36.5\left(d, \mathrm{C}-3_{\mathrm{m}}^{\prime}\right), 35.5(d$, $\left.\mathrm{C}-3_{\mathrm{M}}^{\prime}\right), 26.4\left(t, \mathrm{C}-4_{\mathrm{M}}^{\prime}\right), 25.7\left(t, \mathrm{C}-4_{\mathrm{m}}^{\prime}\right), 18.8(q, \mathrm{C}-6), 15.6(q$, $\left.\mathrm{C}-6_{\mathrm{m}}^{\prime}\right), 14.8\left(q, \mathrm{C}-6_{\mathrm{M}}^{\prime}\right), 12.8(q, \mathrm{C}-7), 11.9\left(q, \mathrm{C}-5^{\prime}\right)$. M: major epimer $3\left(2^{\prime} R, 3^{\prime} S\right)$, m: minor epimer $4\left(2^{\prime} S, 3^{\prime} S\right)$.

\subsection{Absolute configuration determination}

\subsubsection{Oxidation of compounds $\mathbf{1}$ and $\mathbf{2}$ to isoleucine}

A solution of $5 \mathrm{mg}$ of a sample of compounds $\mathbf{1}$ and $\mathbf{2}$ in acetone was oxidized with Jones reagent at ambient temperature (Harding et al., 1975). The product mixture was then subjected to TLC $\left(\mathrm{CH}_{2} \mathrm{Cl}_{2}-\mathrm{MeOH} 85: 15\right)$ yielding the corresponding dicarbonylated intermediates (3-methyl2-(2-oxo-propionylamino)-pentanoic acid). ${ }^{1} \mathrm{HNMR}$ $\left(500 \mathrm{MHz}, \mathrm{CD}_{3} \mathrm{OD}-\mathrm{CDCl}_{3}\right.$ 1:1): $\delta 4.51(d, J=4.0 \mathrm{~Hz}, \mathrm{H}-$ $\left.\alpha_{\mathrm{M}}\right), 4.40\left(d, J=4.8 \mathrm{~Hz}, \mathrm{H}-\alpha_{\mathrm{m}}\right), 2.47\left(\mathrm{CH}_{3} \mathrm{CO}\right), 0.95(t$, $\left.J=6.9 \mathrm{~Hz}, \mathrm{H}-5_{\mathrm{M}}\right), 0.92\left(d, J=6.6 \mathrm{~Hz}, \mathrm{H}-6_{\mathrm{M}}\right)$; M: major epimer, m: minor epimer. The intermediates were hydrolyzed with $6 \mathrm{~N} \mathrm{HCl}$ at $110{ }^{\circ} \mathrm{C}$ for $16 \mathrm{~h}$, with the product neutralized and directly used for HPLC analysis. 
The absolute configuration determination of the aminoacids, derived from 1 and 2, was done by HPLC (Chirex (D) Penicillamine column-Phenomenex, $250 \times 4.60 \mathrm{~mm}$, $\mathrm{CuSO}_{4} 2 \mathrm{mM}$ : $\mathrm{MeOH} 85: 15,0.7 \mathrm{ml} / \mathrm{min}$, UV $215 \mathrm{~nm}$ ) by comparison with authentic standards of amino acids. RT values: L-allo-Ile $25.6 \mathrm{~min}$, L-Ile $29.9 \mathrm{~min}, \quad$ D-allo-Ile 39.9 min, D-Ile $49.5 \mathrm{~min}$. Sample from 1 and 2: 29.9 and $39.9 \mathrm{~min}$. Coinjections confirmed the identities.

\subsection{Synthesis of compounds $\mathbf{1}$ and $\mathbf{2}$}

\subsubsection{Synthesis of (2E,4E)-2-methyl-hexa-2,4-dienoic acid ethyl ester (5)}

This compound was prepared according to the previous reported procedure for the corresponding methyl ester (Ceroni and Séquin, 1982). Instead of the use of Sicapent drying agent, $\mathrm{P}_{2} \mathrm{O}_{5}$ on Silicagel Kieselgel 60 G-Merck (1:2) was employed. Compound 5: Oil. UV $\left(\mathrm{CH}_{2} \mathrm{Cl}_{2}\right) \lambda_{\max }$ $\mathrm{nm}(\log \varepsilon): 236$ (3.4). FTIR (KBr) $v_{\max } \mathrm{cm}^{-1}: 2981(\mathrm{CH})$, $2931(\mathrm{CH}), 1740$ (CO), 1455, 1376, 1241, 1177, 1099, 950. ${ }^{1} \mathrm{H}$ NMR $\left(\mathrm{CDCl}_{3}\right): \delta 7.15(b r d, J=11.4 \mathrm{~Hz}, \mathrm{H}-3), 6.36$ $(d d q, J=15.0,11.4$ and $1.6 \mathrm{~Hz}, \mathrm{H}-4), 6.08(d q, J=15.0$ and $6.8 \mathrm{~Hz}, \mathrm{H}-5), 4.20\left(q, J=7.0 \mathrm{~Hz}, \mathrm{CH}_{2} \mathrm{CH}_{3}\right), 1.92(\mathrm{br}$ $s, \mathrm{H}-7), 1.86(b r d, J=6.8 \mathrm{~Hz}, \mathrm{H}-6), 1.29(t, J=7.0 \mathrm{~Hz}$, $\left.\mathrm{CH}_{2} \mathrm{CH}_{3}\right) \cdot{ }^{13} \mathrm{C}$ NMR $\left(\mathrm{CDCl}_{3}\right): \delta 168.4(s, \mathrm{C}-1), 138.2(d$, C-3), 137.3 (d, C-5), $127.3(d, \mathrm{C}-4), 124.8(s, \mathrm{C}-2), 60.2(t$, $\mathrm{CH}_{2} \mathrm{CH}_{3}$ ), 18.6 (q, C-6), $14.1\left(q, \mathrm{CH}_{2} \mathrm{CH}_{3}\right), 12.3$ (q, C-7). EIMS $70 \mathrm{eV} \mathrm{m} / z$ (rel. int.): $155[\mathrm{M}+1]^{+}(30), 154[\mathrm{M}]^{+}$ (21), 127 (21), 126 (8), 99 (45), 81 (50), 55 (100).

\subsubsection{Hydrolysis of 5 to (2E,4E)-2-methyl-hexa-2,4-dienoic acid (6)}

$\mathrm{NaOH}(4.8 \mathrm{~g})$ was added to a suspension of compound 5 $(18 \mathrm{~g})$ in $t-\mathrm{BuOH}(200 \mathrm{ml})$ and the whole was next heated until reflux began. This was maintained for $1 \mathrm{~h}$, following which compound $6(10.1 \mathrm{~g}, 69 \%)$ was obtained after purification through dry column flash chromatography on silica gel, eluting with EtOAc:cyclohexane 1:1. Amorphous powder. UV $\left(\mathrm{CH}_{2} \mathrm{Cl}_{2}\right) \lambda_{\max }(\mathrm{nm})(\log \varepsilon): 265$ (4.3). FTIR (KBr) $v_{\max }\left(\mathrm{cm}^{-1}\right)$ : $2935(\mathrm{CH}), 2656,2595,1689(\mathrm{CO}), 1640,1612$, 1441, 1305, 1270, 969, 940. ${ }^{1} \mathrm{H}$ NMR $\left(\mathrm{CDCl}_{3}\right): \delta 7.27$ (br d, $J=11.4 \mathrm{~Hz}, \mathrm{H}-3), 6.38(d d q, J=15.1,11.4$ and $1.8 \mathrm{~Hz}, \mathrm{H}-$ 4), $6.15(d q, J=15.1$ and $6.7 \mathrm{~Hz}, \mathrm{H}-5), 1.91(b r s, \mathrm{H}-7)$, $1.89(b r d, J=6.7 \mathrm{~Hz}, \mathrm{H}-6) .{ }^{13} \mathrm{C}$ NMR $\left(\mathrm{CDCl}_{3}\right): \delta 173.9$ (s, C-1), 140.9 (d, C-3), 139.1 (d, C-5), 127.4 (d, C-4), 123.9 (s, C-2), 18.9 (q, C-6), 12.1 (q, C-7). EIMS $70 \mathrm{eV}$, $\mathrm{m} / \mathrm{z}$ (rel. int.): $126[\mathrm{M}]^{+\cdot}(37), 111$ (81), 79 (44), 55 (47), 43 (80), 41 (100).

\subsubsection{Synthesis of $(2 R, 3 S)-3-m e t h y l-2-\left[\left(2^{\prime} E, 4^{\prime} E\right)-2^{\prime}-\right.$} methylhexa-2', $4^{\prime}$-dienoylamino ]- pentanoic acid ethyl ester (7)

$N$-Boc-D-allo-Ile methyl ester was prepared according to the procedure of Hamada et al. (1987). Dry EtOAc saturated with $\mathrm{HCl}$ (vapor) $(5 \mathrm{ml})$ was added to a solution of $N$-Boc-D-allo-Ile methyl ester $(340 \mathrm{mg})$ in dry EtOAc $(5 \mathrm{ml})$. After $5 \mathrm{~h}$ of stirring at room temperature, the crude product was concentrated in vacuo, and was directly employed for the next step. It was dissolved in THF $(10 \mathrm{ml})$ together with compound $6(173 \mathrm{mg})$ and 1 equiv. of pyridine. The mixture was then cooled in an ice bath and dicyclohexylcarbodiimide (DCC) (300 mg) was added. After $30 \mathrm{~min}$, the reaction was allowed to proceed for $4 \mathrm{~h}$ at room temperature. The dicyclohexylurea was removed by filtration (Klausner and Bodanski, 1972). The reaction mixture was evaporated to dryness and the crude product $(150 \mathrm{mg})$ was purified by dry column flash chromatography, eluting fractions with mixtures of cyclohexane$\mathrm{CH}_{2} \mathrm{Cl}_{2}$ 1:1 to $\mathrm{CH}_{2} \mathrm{Cl}_{2}$-EtOAc 1:1 of increasing polarity. Pure compound 7 was eluted with $\mathrm{CH}_{2} \mathrm{Cl}_{2}$. Compound 7 : Oil. $[\alpha]_{\mathrm{D}}=-50\left(\mathrm{CH}_{2} \mathrm{Cl}_{2}, \mathrm{c} 0.49\right)$. UV $\left(\mathrm{CH}_{2} \mathrm{Cl}_{2}\right) \lambda_{\max }(\mathrm{nm})$ $(\log \varepsilon): 240(4.7)$. FTIR $(\mathrm{KBr}) v_{\max }\left(\mathrm{cm}^{-1}\right): 3408(\mathrm{NH})$, $2968(\mathrm{CH}), 2920(\mathrm{CH}), 2860(\mathrm{CH}), 1763(\mathrm{CO}), 1669$, 1520, $1467 .{ }^{1} \mathrm{H}$ NMR $\left(\mathrm{CDCl}_{3}\right): \delta 6.88(b r d, J=11.1 \mathrm{~Hz}$, $\left.\mathrm{H}-3^{\prime}\right), 6.33\left(d d q, J=14.9,11.1\right.$ and $\left.1.6 \mathrm{~Hz}, \mathrm{H}-4^{\prime}\right), 6.18$ $(b r d, J=8.7 \mathrm{~Hz}, \mathrm{NH}), 6.04(d q, J=14.9$ and $6.9 \mathrm{~Hz}, \mathrm{H}-$ $\left.5^{\prime}\right), 4.80(d d, J=8.7$ and $4.1 \mathrm{~Hz}, \mathrm{H}-2), 3.75\left(s, \mathrm{CO}_{2} \mathrm{CH}_{3}\right)$, 1.96 ( $\left.b r s, \mathrm{H}^{\prime} 7^{\prime}\right), 1.97$ (overlapped $m, \mathrm{H}-3$ ), 1.86 ( $b r d$, $\left.J=6.9 \mathrm{~Hz}, \mathrm{H}-6^{\prime}\right), 1.45$ and $1.19(m, \mathrm{H}-4), 0.96(t$, $J=7.3 \mathrm{~Hz}, \mathrm{H}-5), 0.90(d, J=6.8 \mathrm{~Hz}, \mathrm{H}-6) .{ }^{13} \mathrm{C} \mathrm{NMR}$ $\left(\mathrm{CDCl}_{3}\right): \delta 173.1(s, \mathrm{C}-1), 169.1\left(s, \mathrm{C}-1^{\prime}\right), 136.4\left(d, \mathrm{C}-5^{\prime}\right)$, $134.3\left(d, \mathrm{C}-3^{\prime}\right), 127.3\left(s, \mathrm{C}-2^{\prime}\right), 127.0\left(s, \mathrm{C}-4^{\prime}\right), 55.5(d, \mathrm{C}-$ 2), $52.1\left(\mathrm{~s}, \mathrm{CO}_{2} \mathrm{CH}_{3}\right), 38.0(d, \mathrm{C}-3), 26.3(t, \mathrm{C}-4), 18.7(q$, C-6'), 14.7 ( $q$, C-6), 12.8 ( $q$, C-7'), 11.7 ( $q$, C-5). HREIMS $m / z$ : (M) ${ }^{+}$, found 253.16753, calc. for $\mathrm{C}_{14} \mathrm{H}_{23} \mathrm{NO}_{3}$ $253.16779(\Delta m=1.0 \mathrm{ppm})$. EIMS $70 \mathrm{eV}, \mathrm{m} / z$ (rel. int.): $253[\mathrm{M}]^{+\cdot}(24), 238$ (15), 144 (17), 130 (37), 128 (7), 109 $[\mathrm{RCO}]^{+}$(100), 86 (50), 81 (24).

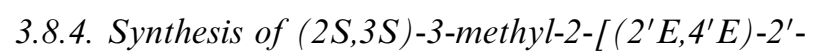
methylhexa-2', $4^{\prime}$-dienoylamino ]- pentanoic acid ethyl ester (8)

The procedure was similar as above. $N$-Boc-L-Ile methyl ester $(400 \mathrm{mg})$ was employed instead of the D-allo-Ile derivative. After purification, compound $8(200 \mathrm{mg})$ was obtained. Compound 8: Oil. $[\alpha]_{\mathrm{D}}=+9\left(\mathrm{CHCl}_{3}, \mathrm{c} 2.72\right)$. $\mathrm{UV}\left(\mathrm{CH}_{2} \mathrm{Cl}_{2}\right) \lambda_{\max }(\mathrm{nm})(\log \varepsilon): 244$ (4.4). FTIR (KBr) $v_{\text {max }}$ $\left(\mathrm{cm}^{-1}\right)$ : $3320(\mathrm{NH}), 2970(\mathrm{CH}), 2929(\mathrm{CH}), 2860(\mathrm{CH})$, 1750 (CO), 1631, 1372, 697. ${ }^{1} \mathrm{H}$ NMR $\left(\mathrm{CDCl}_{3}\right): \delta 6.88$ (br $\left.d, J=11.1 \mathrm{~Hz}, \mathrm{H}-3^{\prime}\right), 6.33(d d q, J=14.9,11.1$ and $\left.1.6 \mathrm{~Hz}, \mathrm{H}-4^{\prime}\right), 6.24(b r d, J=8.4 \mathrm{~Hz}, \mathrm{NH}), 6.04(d q$, $J=14.9$ and $\left.7.0 \mathrm{~Hz}, \mathrm{H}-5^{\prime}\right), 4.68(d d, J=8.4$ and $5.0 \mathrm{~Hz}$, $\mathrm{H}-2), 3.75\left(s, \mathrm{CO}_{2} \mathrm{CH}_{3}\right), 1.96$ ( br s, $\left.\mathrm{H}^{-} 7^{\prime}\right), 1.94(m, \mathrm{H}-3)$, $1.86\left(\right.$ br $\left.d, J=7.0 \mathrm{~Hz}, \mathrm{H}-6^{\prime}\right), 1.48$ and $1.21(m, \mathrm{H}-4), 0.94$ $(t, J=7.4 \mathrm{~Hz}, \mathrm{H}-5), 0.92(d, J=7.0 \mathrm{~Hz}, \mathrm{H}-6) .{ }^{13} \mathrm{C}$ NMR $\left(\mathrm{CDCl}_{3}\right): \delta 172.8(s, \mathrm{C}-1), 168.9\left(s, \mathrm{C}-1^{\prime}\right), 136.4\left(d, \mathrm{C}-5^{\prime}\right)$, $134.3\left(d, \mathrm{C}-3^{\prime}\right), 127.3\left(s, \mathrm{C}-2^{\prime}\right), 127.0\left(d, \mathrm{C}-4^{\prime}\right), 56.5(d, \mathrm{C}-$ 2), $52.0\left(\mathrm{~s}, \mathrm{CO}_{2} \mathrm{CH}_{3}\right), 38.2(d, \mathrm{C}-3), 25.4(t, \mathrm{C}-4), 18.8(q$, C-6'), 15.4 ( $q, \mathrm{C}-6), 12.8\left(q, \mathrm{C}-7^{\prime}\right), 11.6(q, \mathrm{C}-5)$. HREIMS $m / z:(M)^{+*}$, found 253.16899, calc. for $\mathrm{C}_{14} \mathrm{H}_{23} \mathrm{NO}_{3}$ $253.16779(\Delta m=4.7 \mathrm{ppm}),(\mathrm{M}+1)^{+\cdot}$ found 254.17115 , calc. for ${ }^{13} \mathrm{CC}_{13} \mathrm{H}_{23} \mathrm{NO}_{3} 254.17118(\Delta m=1.1 \mathrm{ppm})$. EIMS $70 \mathrm{eV}, m / z$ (rel. int.): $253[\mathrm{M}]^{+}$(9), 238 (4), 224 (4), 144 (14), 128 (12), $109[\mathrm{RCO}]^{+}(100), 81$ (25). 


\subsubsection{Synthesis of compound 1}

$\mathrm{LiBH}_{4}(14 \mathrm{mg})$ and $\mathrm{MeOH}(0.025 \mathrm{ml})$ were added to a solution of compound $7(70 \mathrm{mg})$ in $\mathrm{Et}_{2} \mathrm{O}(2 \mathrm{ml})$. The mixture was heated until reflux began, this being maintained for $15 \mathrm{~min}$, with the resulting reaction mixture poured onto $1 \mathrm{~N} \mathrm{HCl}$ in an ice-bath. The reaction mixture was next extracted with $\mathrm{CH}_{2} \mathrm{Cl}_{2}(3 \times 25 \mathrm{ml})$. The crude evaporated product was subjected to dry column flash chromatography on silica gel, eluting pure compound $1(30 \mathrm{mg})$ with $\mathrm{CH}_{2} \mathrm{Cl}_{2}$ :EtOAc 70:30.

Compound 1. Oil. $[\alpha]_{\mathrm{D}}=-45 \quad\left(\mathrm{CHCl}_{3}, \mathrm{c0} 0.1\right)$. UV $\left(\mathrm{CH}_{2} \mathrm{Cl}_{2}\right) \lambda_{\max }(\mathrm{nm})(\log \varepsilon): 236$ (3.0). FTIR $(\mathrm{KBr}) v_{\max }$ $\left(\mathrm{cm}^{-1}\right): 3321(\mathrm{NH}), 2932,2846,1742,1489,1380,1193$. ${ }^{1} \mathrm{H}$ NMR $\left(\mathrm{CDCl}_{3}\right): \delta 6.90(b r d, J=10.8 \mathrm{~Hz}, \mathrm{H}-3), 6.33$ $(d d q, J=14.8,10.8$ and $1.6 \mathrm{~Hz}, \mathrm{H}-4), 6.04(d q, J=14.8$ and $6.9 \mathrm{~Hz}, \mathrm{H}-5), 5.90(b r d, J=8.0 \mathrm{~Hz}, \mathrm{NH}), 4.00(m$, $\left.\mathrm{H}-2^{\prime}\right), 3.69$ (m, H-1'), $1.96(b r s, \mathrm{H}-7), 1.86(b r d$, $J=6.9 \mathrm{~Hz}, \mathrm{H}-6), 1.70\left(m, \mathrm{H}-3^{\prime}\right), 1.44$ and $1.25\left(m, \mathrm{H}-4^{\prime}\right)$, $0.93\left(t, J=7.3 \mathrm{~Hz}, \mathrm{H}-5^{\prime}\right), 0.93\left(d, J=6.9 \mathrm{~Hz}, \mathrm{H}-6{ }^{\prime}\right) .{ }^{13} \mathrm{C}$ NMR $\left(\mathrm{CDCl}_{3}\right): \delta 170.3(s, \mathrm{C}-1), 136.3(d, \mathrm{C}-5), 134.2(d$, C-3), $127.3(s, \mathrm{C}-2), 126.9(d, \mathrm{C}-4), 64.3\left(t, \mathrm{C}-1^{\prime}\right), 55.3$ $\left(d, \mathrm{C}-2^{\prime}\right), 35.5\left(d, \mathrm{C}-3^{\prime}\right), 26.3\left(t, \mathrm{C}-4^{\prime}\right), 18.7(q, \mathrm{C}-6), 14.8$ $\left(q, \mathrm{C}^{\prime} 6^{\prime}\right), 12.8(q, \mathrm{C}-7), 11.3\left(q, \mathrm{C}^{\prime} 5^{\prime}\right)$. HREIMS $m / z$ : $(\mathrm{M})^{+\cdot}$, found 225.17263 , calc. for $\mathrm{C}_{14} \mathrm{H}_{23} \mathrm{NO}_{3} 225.17288$ $(\Delta m=1.1 \mathrm{ppm})$. EIMS $70 \mathrm{eV}, \mathrm{m} / \mathrm{z}$ (rel. int.): 225 $[\mathrm{M}]^{+\cdot}(8), 194$ (22), 109 [RCO $^{+}$(100), 86 (62).

\subsubsection{Synthesis of compound 2}

The procedure was similar as above. Compound 8 $(150 \mathrm{mg})$ was employed instead of 7. After purification, pure compound $2(80 \mathrm{mg})$ was obtained. Compound 2: Oil. $[\alpha]_{\mathrm{D}}=+72\left(\mathrm{CH}_{2} \mathrm{Cl}_{2}, \mathrm{c} 0.37\right)$. UV $\left(\mathrm{CH}_{2} \mathrm{Cl}_{2}\right) \lambda_{\max }(\mathrm{nm})(\log \varepsilon)$ : 240 (4.0). FTIR (KBr) $v_{\max }\left(\mathrm{cm}^{-1}\right): 3390(\mathrm{NH}), 2968,2939$, $1662,1539,1467,1388,1085 .{ }^{1} \mathrm{H}$ NMR $\left(\mathrm{CDCl}_{3}\right): \delta 6.88(\mathrm{br}$ $d, J=10.8 \mathrm{~Hz}, \mathrm{H}-3), 6.33(d d q, J=14.8,10.8$ and $1.5 \mathrm{~Hz}$, $\mathrm{H}-4), 6.03(d q, J=14.8$ and $6.9 \mathrm{~Hz}, \mathrm{H}-5), 6.00$ (overlapped, $\mathrm{NH}), 3.88$ ( $\left.m, \mathrm{H}-2^{\prime}\right), 3.73\left(\mathrm{~m}, \mathrm{H}-1^{\prime}\right), 1.95$ ( $\left.b r \mathrm{~s}, \mathrm{H}-7\right), 1.86(\mathrm{br}$ $d, J=6.9 \mathrm{~Hz}, \mathrm{H}-6), 1.70\left(m, \mathrm{H}-3^{\prime}\right), 1.50$ and $1.22\left(m, \mathrm{H}-4^{\prime}\right)$, $0.95\left(d, J=6.8 \mathrm{~Hz}, \mathrm{H}-6^{\prime}\right), 0.91\left(t, J=7.0 \mathrm{~Hz}, \mathrm{H}-5^{\prime}\right) .{ }^{13} \mathrm{C}$ NMR $\left(\mathrm{CDCl}_{3}\right): \delta 170.0(s, \mathrm{C}-1), 136.4(d, \mathrm{C}-5), 134.2(d$, $\mathrm{C}-3), 127.2(s, \mathrm{C}-2), 127.0(d, \mathrm{C}-4), 63.7\left(t, \mathrm{C}-1^{\prime}\right), 56.2$ (d, C-2'), $35.7\left(d\right.$, C-3'), 25.4 ( $\left.t, \mathrm{C}-4^{\prime}\right), 18.7$ (q, C-6), 15.5 $\left(q, \mathrm{C}^{\prime} 6^{\prime}\right), 12.7(q, \mathrm{C}-7), 11.6\left(q, \mathrm{C}-5^{\prime}\right)$. HREIMS $\mathrm{m} / \mathrm{z}$ : $(\mathrm{M})^{+\cdot}$, found 225.17197, calc. for $\mathrm{C}_{14} \mathrm{H}_{23} \mathrm{NO}_{3} 225.17288$ $(\Delta m=4.0 \mathrm{ppm})$. EIMS $m / z$ (rel. int.): $225[\mathrm{M}]^{+\cdot}$ (5), 210

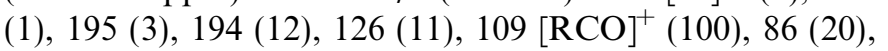
$81(28)$.

\subsubsection{Synthesis of N-Boc-L-isoleucinaldehyde (10)}

$N$-Boc-L- isoleucinol $9(172 \mathrm{mg})$, prepared from $N$-BocL-Ile methyl ester in the same way as above, was oxidized with pyridinium chlorochromate (PCC) according to Corey and Suggs (1975), to yield compound 10 (152 mg). An aliquot of the product $(50 \mathrm{mg})$ was purified by prep. TLC $\left(\mathrm{CH}_{2} \mathrm{Cl}_{2}\right.$-EtOAc 95:5, $\left.R_{\mathrm{F}}=0.6\right)$. Compound 10: Oil. $[\alpha]_{\mathrm{D}}=+71\left(\mathrm{CH}_{2} \mathrm{Cl}_{2}, \mathrm{c} 0.12\right)$. UV $\left(\mathrm{CH}_{2} \mathrm{Cl}_{2}\right) \lambda_{\max }(\mathrm{nm})(\log \varepsilon):$ 234 (3.5). ${ }^{1} \mathrm{H}$ NMR $\left(\mathrm{CDCl}_{3}\right): \delta: 9.66(s, \mathrm{H}-1), 5.13$ (br d,
$J=8.0 \mathrm{~Hz}, \mathrm{NH}), 4.29(m, \mathrm{H}-2), 1.70(m, \mathrm{H}-3), 1.47$ (overlapped, $\mathrm{H}-4), 1.45\left(s, \mathrm{C}\left(\mathrm{CH}_{3}\right)_{3}\right), 1.27(m, \mathrm{H}-4), 0.99(d$, $J=6.9 \mathrm{~Hz}, \mathrm{H}-6), 0.96(t, J=7.3 \mathrm{~Hz}, \mathrm{H}-5) .{ }^{13} \mathrm{C}$ NMR $\left(\mathrm{CDCl}_{3}\right): \delta 200.6(d, \mathrm{C}-1), 156.9(s, \mathrm{NCOO}), 79.6(s$, $\left.C\left(\mathrm{CH}_{3}\right)_{3}\right) 64.2(d, \mathrm{C}-2), 36.4(d, \mathrm{C}-3), 28.3\left(s, \mathrm{C}\left(\mathrm{CH}_{3}\right)_{3}\right)$, $25.3(t, \mathrm{C}-4), 15.6$ ( $q$, C-6), 11.9 ( $q$, C-5). HREIMS $m / z$ : $(\mathrm{M})^{+\cdot}$, found 215.15258 , calc. for $\mathrm{C}_{14} \mathrm{H}_{23} \mathrm{NO}_{3} 215.15214$ $(\Delta m=2 \mathrm{ppm})$. EIMS $m / z$ (rel. int.): $215[\mathrm{M}]^{+\cdot}(50), 186$ (27), 130 (88), 86 (79), 57 (100).

\subsubsection{Antibiotic activity}

The antibiotic activity was determined by the agar diffusion method using $50 \mu \mathrm{g}$ of sample/ $6 \mathrm{~mm}$ disk against $B$. subtilis ATCC 6633, S. aureus ATCC 25923 and E. coli ATCC 25922. Gentamicin, which was used as the positive test compound, showed inhibition halos of $25-30 \mathrm{~mm}$ at a conc. level of $25 \mu \mathrm{g} /$ disk.

\subsubsection{Antifungal activity}

Direct bioautography on TLC was employed as the method for detecting fungitoxic substances (Homans and Fuchs, 1970). A concentration level of $50 \mu \mathrm{g} / \mathrm{spot}$ of each assayed compound was used. Benomyl, which was used as a control, showed inhibition zones of $20-28 \mathrm{~mm}$ at a conc. level of $25 \mu \mathrm{g} / \mathrm{spot}$. When appropriate, as large inhibitory halos were observed, minimum inhibitory concentration (MIC) was measured by the same method.

\section{Acknowledgements}

We thank UMYMFOR (CONICET-FCEN, UBA) for the NMR and LR-MS spectra and Universidad de Buenos Aires, ANPCYT and CONICET for partial financial support.

\section{References}

Abdel-Lateff, A., König, G.M., Fisch, K.M., Holler, U., Jones, P.G., Wright, A.D., 2002. New antioxidant hydroquinone derivatives from the algicolous marine fungus Acremonium sp.. J. Nat. Prod. 65, 16051611.

Belofsky, G.N., Anguera, M., Jensen, P.R., Fenical, W., Kock, M., 2000. Oxepinamides $\mathrm{A}-\mathrm{C}$ and fumiquinazolines $\mathrm{H}-\mathrm{I}$ : bioactive metabolites from a marine isolate of a fungus of the genus Acremonium. Chemistry - Eur. J. 6, 1355-1360.

Bringmann, G., Lang, G., Gulder, T.A.M., Tsuruta, H., Mühlbacher, J., Maksimenka, K., Steffens, S., Schaumann, K., Stöhr, R., Wiese, J., Imhoff, J.F., Perovic'-Ottstadt, S., Boreiko, O., Müller, W.E.G., 2005. The first sorbicillinoid alkaloids, the antileukemic sorbicillactones A and $\mathrm{B}$, from a sponge-derived Penicillium chrysogenum strain. Tetrahedron 61, 7252-7265.

Cabrera, G.M., Roberti, M.J., Wright, J.E., Seldes, A.M., 2002. Cryptoporic and isocryptoporic acids from the fungal cultures of Polyporus arcularius and P. ciliatus. Phytochemistry 61, 189-193.

Ceroni, M., Séquin, U., 1982. Determination of the relative configurations in the side chains of the antibiotics hedamycin and pluramycin A: synthesis and NMR. Data of suitable model compounds. Helv. Chim. Acta $65,302-316$. 
Che, Y., Gloer, J.B., Koster, B., Malloch, D., 2002. Decipinin A and decipienolides $\mathrm{A}$ and $\mathrm{B}$ : new bioactive metabolites from the coprophilous fungus Podospora decipiens. J. Nat. Prod. 65, 916-919.

Christophersen, C., Crescente, O., Frisvad, J.C., Gram, L., Nielsen, J., Nielsen, P.H., Rabaek, L., 1999. Antibacterial activity of marinederived fungi. Mycopathologia 143, 135-138.

Corey, E.J., Suggs, J.W., 1975. Pyridinium chlorochromate. An efficient reagent for oxidation of primary and secondary alcohols to carbonyl compounds. Tetrahedron Lett. 31, 2647-2650.

Davidson, B.S., 1995. New dimensions in natural products research: cultured marine microorganisms. Curr. Opin. Biotechnol. 6, 284-291.

Fenical, W., Jensen, P.R., 1993. Marine microorganisms: a new biomedical resource. In: Attaway, D.H., Zaborsky, O.R. (Eds.), Marine Biotechnology, vol. 1. Plenum Press, pp. 419-457.

Gallo, M.L., Seldes, A.M., Cabrera, G.M., 2004. Antibiotic long-chain and $\alpha, \beta$-unsaturated aldehydes from the culture of the marine fungus Cladosporium sp. Biochem. Syst. Ecol. 32, 545-551.

Hamada, Y., Shibata, M., Sugiura, T., Kato, S., Shioiri, T., 1987. New methods and reagents in organic synthesis. 67. A general synthesis of derivatives of optically pure 2-(1-aminoalkyl)thiazole-4-carboxylic acids. J. Org. Chem. 52, 1252-1255.

Harding, K.E., May, L.M., Dick, K.F., 1975. Selective oxidation of allylic alcohols with chromic acid. J. Org. Chem. 40, 1664-1665.

Homans, A.L., Fuchs, A., 1970. Direct bioautography on thin-layer chromatography as a method for detecting fungitoxic substances. J. Chromatogr. 51, 325-328.

Iwamoto, T., Fujiie, A., Tsurumi, Y., Nanbata, K., Shibuya, K., 1990. FR900403, a new antifungal produced by a Kernia sp.. J. Antibiot. 43, $1183-1185$

Jaworski, A., Bruckner, H., 2001. Sequences of polypeptide antibiotics stilboflavins, natural peptaibol libraries of the mold Stilbella flavipes. J. Pept. Sci. 7, 433-447.

Kawakami, Y., Matsuwaka, S., Otani, T., Kondo, H., Nakamura, S., 1978. Ileumycin, a new antibiotic against Glomerella cingulata. J. Antibiot. 31, 112-116.

Kawashima, J., Ito, F., Kato, T., Niwano, M., Koshino, H., Uramoto, M., 1994. Antitumor activity of heptelidic acid chlorohydrin. J. Antibiot. 47, 1562-1563.

Kennedy, T.C., Webb, G., Cannell, R.J.P., Kinsman, O.S., Middletton, R.F., Sidebottom, P.J., Taylor, N.L., Dawson, M.J., Buss, A.D., 1998.
Novel inhibitors of fungal protein synthesis produced by a strain of Graphium putredinis. Isolation, characterization and biological properties. J. Antibiot. 51, 1012-1018.

Kern, A., Kabatek, U., Jung, G., Werner, R.G., Poetsch, M., Záhner, H., 1985. Amiclenomycin peptides. Isolation and structure elucidation of new biotin antimetabolites. Liebigs Ann. Chem., 877.

Klausner, Y., Bodanski, M., 1972. Coupling reagents in peptide synthesis. Synthesis, 453-463.

Kobayashi, J., Ishibashi, M., 1993. Bioactive metabolites of symbiotic marine microorganisms. Chem. Rev. 93, 1753-1769.

Koh, L.L., Tan, T.K., Chou, L.M., Goh, N.K.C., 2002. Antifungal properties of Singapore gorgonians: a preliminary study. J. Exp. Mar. Biol. Ecol. 273, 121-130.

Levy, L.M., Cabrera, G.M., Wright, J.E., Seldes, A.M., 2003. $5 H$-furan-2ones from the culture of the fungus Aporpium caryae. Phytochemistry $62,239-242$.

MacDonald, J.C., Bishop, G.G., Mazurek, M., 1976. Empirical equations for predicting ${ }^{13} \mathrm{C}$ chemical shifts in nuclear magnetic resonance spectra of certain types of aminoacids. Can. J. Chem. 54, 1226-1233.

Munday-Finch, S.C., Miles, C.O., Wilkins, A.L., Hawkes, A.D., 1995. Isolation and structure elucidation of lolitrem A, a tremorgenic mycotoxin from perennial ryegrass infected with Acremonium lolii. J. Agric. Food Chem. 43, 1283-1288.

Proksa, B., Adamcová, J., Fuska, J., 1992. 2-Methylsorbic acid, an antifungal metabolite of Penicillium vermiculatum. Appl. Microbiol. Biotechnol. 37, 443-445.

Rabaek, L., Sperry, S., Piper, J.E., Crews, P., 1998. Deoxynortrichoharzin, a new polyketide from the saltwater culture of a sponge-derived Paecilomyces fungus. J. Nat. Prod. 61, 1571-1573.

Schiehser, G.A., White, J.D., Matsumoto, G., Pezzanite, J.O., Clardy, J., 1986. The structure of leptosphaerin. Tetrahedron Lett. 27, 5587-5590.

Sharman, G.J., Try, A.C., Williams, D.H., Ainsworth, A.M., Beneyto, R., Gibson, T.M., McNicholas, C., Renno, D.V., Robinson, N., Wood, K.A., Wrigley, S.K., 1996. Structural elucidation of XR586, a peptaibol-like antibiotic from Acremonium persicinum. Biochem. J. 320, 723-728.

Toki, S., Ando, K., Yoshida, M., Matsuda, Y., 1994. PS-990, a novel neuritogenic compound from Acremonium sp. J. Antibiot. 47, 11751181. 